\title{
The Effect of Authentic Problem-Based Vocabulary Tasks on Vocabulary Learning of EFL Learners
}

Fateme Shir Mohammadi*

Allameh Tabatabai University, Iran

Corresponding author: Fateme Shir Mohammadi, E-mail: fa.mohamadi@yahoo.com

\begin{tabular}{l} 
ARTICLE INFO \\
\hline Article history \\
Received: May 23, 2017 \\
Accepted: June 19, 2017 \\
Published: July 31, 2017 \\
Volume: $5 \quad$ Issue: 3 \\
\hline
\end{tabular}

Conflicts of interest: None Funding: None

\begin{abstract}
Language learners' cognitive engagement with the content in language classes has been advocated in the last few decades (Laufer \& Hulstjin, 2001). To this end, the researcher designed authentic problem-based tasks which make use of learners' cognitive and metacognitive skills to solve real-life vocabulary tasks. Nelson vocabulary test was administered to 64 Iranian EFL learners studying at a language institute in Tehran. By considering 1 standard deviation above and below the mean score, two cohorts of participants were selected for this study, i.e. the experimental group $(n=24)$ and the control group $(n=23)$. Conventional vocabulary learning tasks were implemented in the control group classes for 10 sessions while authentic problembased vocabulary learning tasks were implemented in experimental group classes. The results of data analysis revealed that the experimental group participants outperformed the control group learners in both tests of vocabulary recall and vocabulary retention (administered after a twoweek interval). Pedagogical Implications are discussed.
\end{abstract}

Key words: Vocabulary Learning, Authentic Problem-Based Tasks, Problem-Based Learning,

Recall, Retention

\section{INTRODUCTION}

Vocabulary is in no certain terms one of the most significant components of communication in both first language (L1) and second language (L2). As a result, it has been subject of intense study in the field of applied linguistics. Wilkins (1972) acknowledged vocabulary as a sine qua non in communication and asserted that without vocabulary nothing can be communicated, whereas without grammar communication takes place partially. Mar-Molinero and Stevensons (2016) also acknowledged the prime role of vocabulary as a linguistic feature and noted that learning vocabulary in L2 is more cumbersome than acquisition of vocabulary in L1, as speakers of a language learn their mother-tongue vocabulary effortlessly, but in L2 language learners should pass the challenges of vocabulary learning.

The difficulties associated with learning English as a foreign language (EFL) and learning English as the Second Language (ESL) with regard to vocabulary learning has resulted in a series of studies which aimed at making this process less troublesome. Laufer and Hulstjin's (2001) Involvement Load Hypothesis, and Nation's (2001) clarification of vocabulary learning needs and processes are among the most significant efforts. However, it would be hard to claim all approaches to vocabulary learning have been studied so far. One of the recent approaches to language learning which might have effect on vocabulary learning is problem-based learning (PBL). PBL is a collaborative, self-directed approach to learning which makes use of language learners' cognitive and metacognitive thinking skills (Ansarian, Adlipour, Saber, Shafiei, 2016). PBL tasks aim at mimicking real-life problems in learning (Savery, 2006); believing that what language learners learn should have similarities with their real-life problems. In such a way, the problems designed for language learners are authentic. In addition, PBL, as opposed to traditional approaches to learning, views learning as a process of analyzing and decoding the content, a process which results in longer term retention of knowledge (Boud \& Feletti, 2008).

The possible effect of PBL on EFL learners' vocabulary learning motivated the researcher to conduct a study and investigate the impact of authentic problem-based tasks on vocabulary learning of Iranian EFL learners.

Although many efforts are made by language teachers to facilitate learning vocabulary items of the new language for the language learners, many of the new words are subject to learners' obliviousness. Boud (1995) asserts that the main reason for low retention of knowledge is memorization instead of comprehension. Comprehension, as cited in Richards (1985) Bloom's hierarchy of thinking, requires evaluation of the learning content in a way that results in formation of conjectures in the minds of the learners about how to find a possible answer to the learning question. However, most language classes in Iran do not provide the learners with such an opportunity; teachers in these classes act as "sages 
of stage" and decode the learning materials for the language learners (Akbari, 2015). Many classroom techniques used in the EFL context of Iran for learning vocabulary such as repetition and substitution result in rote learning which puts the content at the risk of being forgotten. Eventually, language learners should try hard to learn vocabulary. This is for sure not a desired situation for both language learners and teachers.

On the other hand, PBL claims to make use of language learners' higher order thinking skills which target both effective learning and long term retention of content. As a result, PBL may have effect on learning vocabulary and provide a solution to this problem.

PBL is an innovative approach to education in the field of language learning. Larsson (2001) called for more studies dealing with PBL and language learning; believing that providing a robust answer to the question of whether PBL can affect language learning requires more empirical studies. Moreover, PBL may affect both recall and retention of vocabulary items. As such, the effect can pave the way for this approach to be implemented in language classes, this study can contribute to the field in terms of vocabulary learning.

\section{Objectives}

This study had two main objectives:

1. To investigate the effect of authentic problem-based tasks on recall of vocabulary items by Iranian EFL learners at intermediate level.

2. To find out whether or not authentic problem-based tasks also affect retention of vocabulary items by Iranian EFL learners.

\section{Research Question}

1. Do authentic problem-based tasks have any effect on recall of vocabulary items by Iranian EFL learners at intermediate level?

2. Do authentic problem-based tasks have any effect on retention of vocabulary items by Iranian EFL learners at intermediate level?

\section{Research Hypothesis}

H01: Authentic problem-based tasks do not have any effect on recall of vocabulary items by Iranian EFL learners at intermediate level.

H02: Authentic problem-based tasks do not have any effect on retention of vocabulary items by Iranian EFL learners at intermediate level.

\section{REVIEW OF THE LITERATURE}

\section{Theoretical Background}

As a multidisciplinary approach to education, PBL utilizes a number of theories. The main theory used in this study is constructivism. In contrast to positivist who regarded reality as an observable entity which is fixed in nature, PBL seeks the answers to the problems as perceived by the language learners. As a result, many sources in the literature have considered this approach to be a constructivist approach to education (see for example, Savery, 2006; Hmelo-Silver, 2004). The researcher acknowledges that there are no fixed correct answers in PBL tutorship and as long as the language learners can solve the communicative problem exposed to them, the answer is correct.

The second theory is Bloom's Higher Order Thinking Skill, as presented by Ansarian et al. (2016). In this model, learning takes place as a result of critically evaluating the problems rather than attempting to memorize the content. Six levels of Bloom's model are 1) evaluation, 2) synthesis. 3) analysis, 4) application, 5)comprehension, and 6) knowledge, respectively.

Hmelo-Silver's (2004) model for practical implementation of PBL was used. Based on the model, the learning process begins by exposing a real-life problem to the students, generating hypothesis about the problem, application of hypotheses to check them, reapplication after amendment (through peer and tutor feedback).

It should be mentioned that PBL is a real-life approach to solve the problems. Therefore, the approaches one can adopt to solve problems is not fixed. Likewise, the way PBL can be implemented is not fixed although this has led to misconceptions about PBL, and eventually, misapplication of this new approach. We attempted to solve this problem by extracting the teaching method based on the afore-mentioned theories. The process used to conduct the study is explained in the procedure section.

\section{Historical Background}

PBL emerged in education as a reform in 1960s. It was first used in higher education to teach medical and nursing students (Lee \& Kwan, 2014). Later, due to its success with medical students, this approach found its way to other disciplines such as engineering, chemistry and geography (Savery, 2006) and to high schools, middle school and even elementary schools (Boud \& Feletti, 1991). The presence of $\mathrm{PBL}$ in language classes was observed only in the last two decades (Ansarian, adlipour, Saber, \& Shafiei, 2016). Having entered humanities and language education, PBL was implemented and evaluated in various contexts. For example, Azman and Shin (2012) investigated language learners' perception about the use of PBL in language classes in a local university in Malaysia. Coffin (2013) investigated the impact of implementing PBL in Thai context. Ansarian et al. (2016) gauged the effect of PBL on speaking proficiency of Iranian EFL learners.

Although focus has been accorded to the roles of PBL in language classes, the effect of PBL on many language skills, sub-skills and affective factors in language classes is not fully understood, which is due to sparse literature. Therefore, this study attempted to provide documented evidence of the effect of PBL on vocabulary learning in the EFL context of Iran. 


\section{METHOD}

\section{Research Design}

This study adopts a quasi-experimental design due to using quota sampling method. The main independent variable in this study is the problem-based vocabulary tasks, and the main dependent variable is vocabulary learning. Vocabulary learning is sought in terms of both recall and retention of words by the participants.

\section{Participants}

The participants in this study were selected from a language institute in the city of Tehran, Iran. Nelson vocabulary proficiency test was administered to 64 female language learners who were studying at the intermediate level in the. Based on the results gained from the test and by considering 1 standard deviation above and below the mean score, 47 learners were opted. These participants were divided into a control group $(n=23)$ and an experimental group $(n=24)$.

\section{Instruments}

The instruments used in the study are as follows:

\section{Nelson vocabulary proficiency test}

Nelson Vocabulary Proficiency Test is a thirty-item vocabulary test. The test is designed for intermediate language learners. The test was used as a homogeneity test in this study. Based on the results of the test the participants were divided into a control group and an experimental group.

\section{Vocabulary knowledge scale}

Wesche and Paribakht's (1996) vocabulary knowledge scale was utilized in this study to select the vocabulary items the participants did not know prior to the study. Ninety-five vocabulary items (Appendix A) were tested through this scale and 30 items were selected to be taught in the course. The same items were used to design the post-test for the study which included 30 items.

\section{Researcher-made post-test}

The researcher designed a post-test based on the vocabulary taught in the course of treatment. The test consisted of 30 multiple-choice items. Item analysis was run to measure ratios of item discrimination (ID) and Item Facility (IF) in the test. The reliability of the test was also measured using Cronbach Alpha $(\alpha=.85)$.

\section{Procedure}

The intervention phase of the study lasted for 12 sessions over the period of 1 month. Every session lasted for 45 minutes and there were 3 sessions in each week. The control group participants practiced the vocabulary through an input-based approach which was the conventional ap- proach used in the language institute where the study was conducted. The teacher introduced the vocabulary items to the participants by jotting down them on the board. The participants were asked if they know the meaning of the words. The teacher then clarified the meaning of the words through different techniques such as role-playing, drawing pictures, and explanation. The participants were asked to copy the words in their notebooks and to make both written and oral sentences using the words. Finally, they were asked to work in groups and ask and answer questions which required using the newly learnt words in the response.

The participants in the experimental group went through a different procedure. In each session, the teacher introduced a real-life scenario to the participants. For example, in session two in which the target vocabulary items were leaky, destroy and life expenses. The following scenario was given to the participants:

Imaging the taps in your apartment are dripping. You want your landlord to solve the problem. What would you do?

Students in groups of 2 to 3 thought about the problem and generated hypotheses about how they could solve the problem. Some decided to write a letter to the landlord. Some preferred to make a phone call. Next, they prepared a list of problems to be mentioned in the conversation. They searched online using their cell phones for other required words and also elicited vocabulary items from each other. Finally, they created a conversation. The conversations were evaluated by the teacher and the peers in the class for clarity of representing ideas and for its potential to achieve the conversation goal. Amendments were made if necessary and conversations were role played for all class members. This procedure was similarly conducted for all intervention sessions in the experimental group. Following the treatment, all participants received the researcher-made post-test.

\section{DATA ANALYSIS}

Statistical package in social sciences (SPSS) version 22 was used to find the answer to the research questions. Before the main analysis, distribution of the data was checked. Table 1 shows ratios of skewness and kurtosis over their respective standards for all tests.

As can be observed in Table 1, ratios of skewness and kurtosis are within the range of \pm 1.96 . This indicated normal distribution of data (Strevens, 2009), thus normal distribution of data for all tests was assumed.

Next, the researcher made sure that the difference between the participants' vocabulary scores in the two groups was insignificant prior to the study. Therefore, independent samples t-test was run. As can be noticed in Table 2, the difference between the experimental group's mean $(\mathrm{M}=16.66$, $\mathrm{SD}=1.46)$ and the control group's mean $(\mathrm{M}=16.68, \mathrm{SD}=$ $1.44)$ prior to the main study is very small.

Noticing Table 2, the results of independent samples $\mathrm{t}$-test $(\mathrm{t}(45)=-0.35, \mathrm{Sig}=.972)$ indicated that the difference between the groups is not significant. 


\section{The First Research Question}

Q1: Do authentic problem-based tasks have any effect on recall of vocabulary items by Iranian EFL learners at intermediate level?

The answer to the first research question was investigated through independent samples t-test. In this case, the posttest results of both groups in the immediate posttest were compared.

Noticing Table 3, there is a difference between the mean score of the participants in the experimental group $(\mathrm{M}=19.62, \mathrm{SD}=1.99)$ and the control group participants $(\mathrm{M}=18.13, \mathrm{SD}=1.54)$. Also, independent samples t-test results $(\mathrm{t}(45)=2.861, \mathrm{Sig}=.006)$ indicate a significant difference between the posttest scores of the control group and the experimental group; therefore, the first null hypothesis was rejected, and it can be assumed that authentic problem-based tasks have effect on recall of vocabulary items by Iranian EFL learners at intermediate level.

\section{The Second Research Question}

Q2: Do authentic problem-based tasks have any effect on retention of vocabulary items by Iranian EFL learners at intermediate level?

In order to seek the answer to the second research question, independent samples t-test was run between the control group and the experimental group's delayed posttest results.

As noticed in Table 4, there was a difference between the posttest scores of the participants in the experimental group $(\mathrm{M}=19.20, \mathrm{SD}=1.26)$ and control group participants $(\mathrm{M}=17.39, \mathrm{SD}=1.67)$. In addition, the results of independent samples t-test $(\mathrm{t}(45)=3.11, \mathrm{Sig}=.003)$ indicates that there is a significant effect. Therefore, the second null hypothesis was rejected and authentic problem-based tasks have effect on retention of vocabulary items by Iranian EFL learners at intermediate level.

\section{DISCUSSION AND CONCLUSION}

This study revealed that authentic problem-based tasks could have significant positive effect on vocabulary learning of Iranian EFL learners in terms of recall and retention. Many of the previous research findings in the field of PBL and language teaching are in line with the findings of this study. Laufer and Hulstjin (2001) who discussed the significance of involvement with the learning content in language classes through involvement-load hypothesis believed that cognitive involvement is a significant asset to depth of processing hypothesis. In other words, language learners' learning may be more or less effective based on the approach they select to learn vocabulary. On the other hand, Bloom's higher order thinking model which was implemented in the treatment through authentic problem-based tasks makes use of students' cognitive and meta-cognitive skills to solve problems. As a result, it can be concluded that authentic problem-based tasks increase language learners' cognitive involvement with the learning content and result in more effective vocabulary learning.

Table 1. Distribution of scores in all tests

\begin{tabular}{|c|c|c|c|c|c|c|c|}
\hline & \multirow{2}{*}{$\begin{array}{c}\text { N } \\
\text { Statistic }\end{array}$} & \multirow{2}{*}{$\begin{array}{c}\text { Mean } \\
\text { Statistic }\end{array}$} & \multirow{2}{*}{$\begin{array}{c}\begin{array}{c}\text { Standard } \\
\text { deviation }\end{array} \\
\text { Statistic }\end{array}$} & \multicolumn{2}{|c|}{ Skewness } & \multicolumn{2}{|c|}{ Kurtosis } \\
\hline & & & & Statistic & $\begin{array}{c}\text { Standard } \\
\text { error }\end{array}$ & Statistic & $\begin{array}{c}\text { Standard } \\
\text { error }\end{array}$ \\
\hline Nelson & 65 & 17.476 & 2.325 & 0.349 & 0.297 & -0.239 & 0.586 \\
\hline Experimental-pretest & 24 & 16.666 & 1.464 & -0.812 & 0.472 & 0.334 & 0.918 \\
\hline Control-pretest & 23 & 16.608 & 1.469 & -0.752 & 0.481 & 0.287 & 0.935 \\
\hline Immediate-posttest-control & 23 & 18.130 & 1.546 & 0.086 & 0.481 & -0.236 & 0.935 \\
\hline Immediate-posttest-experimental & 24 & 19.625 & 1.995 & 0.211 & 0.472 & -0.282 & 0.918 \\
\hline Delayed-posttest-experimental & 24 & 19.208 & 1.264 & 0.456 & 0.654 & 0.345 & 0.922 \\
\hline Delayed-posttest-control & 23 & 17.391 & 1.671 & 0.453 & 0.684 & 0.543 & 0.922 \\
\hline
\end{tabular}

Table 2. Independent samples t-test; pretest of groups

\begin{tabular}{|c|c|c|c|c|c|c|c|c|c|}
\hline \multirow[t]{2}{*}{ Pretest } & \multicolumn{2}{|c|}{ Control } & \multicolumn{2}{|c|}{ Experimental } & \multirow[t]{2}{*}{$\mathbf{t}$} & \multirow[t]{2}{*}{ df } & \multirow[t]{2}{*}{ Sig } & \multicolumn{2}{|c|}{$\begin{array}{l}95 \% \text { confidence interval of } \\
\text { the difference }\end{array}$} \\
\hline & M & SD & M & SD & & & & Lower & Higher \\
\hline & 16.68 & 1.46 & 16.66 & 1.44 & -0.35 & 45 & 0.972 & -0.88 & 0.85 \\
\hline
\end{tabular}

Table 3. Independent samples t-test, immediate posttest results of the groups

\begin{tabular}{|c|c|c|c|c|c|c|c|c|c|}
\hline \multirow[t]{2}{*}{ Posttest } & \multicolumn{2}{|c|}{ Control } & \multicolumn{2}{|c|}{ Experimental } & \multirow[t]{2}{*}{$\mathbf{t}$} & \multirow[t]{2}{*}{ df } & \multirow[t]{2}{*}{ Sig } & \multicolumn{2}{|c|}{$\begin{array}{l}95 \% \text { confidence interval of } \\
\text { the difference }\end{array}$} \\
\hline & M & SD & M & SD & & & & Lower & Higher \\
\hline & 18.13 & 1.54 & 19.62 & 1.99 & 2.86 & 45 & 0.006 & 0.44 & 2.54 \\
\hline
\end{tabular}


Table 4. Independent samples T-test; delayed posttest of vocabulary

\begin{tabular}{|c|c|c|c|c|c|c|c|c|c|}
\hline \multirow[t]{2}{*}{ Posttest } & \multicolumn{2}{|c|}{ Control } & \multicolumn{2}{|c|}{ Experimental } & \multirow[t]{2}{*}{ t } & \multirow[t]{2}{*}{ df } & \multirow[t]{2}{*}{ Sig } & \multicolumn{2}{|c|}{$\begin{array}{l}95 \% \text { confidence interval of } \\
\text { the difference }\end{array}$} \\
\hline & M & SD & M & SD & & & & Lower & Higher \\
\hline & 17.39 & 1.67 & 19.20 & 1.26 & 3.11 & 45 & 0.003 & 0.64 & 2.09 \\
\hline
\end{tabular}

In terms of retention of vocabularies, this study revealed that authentic problem-based vocabulary tasks lead to more retention of knowledge compared to conventional input-based vocabulary learning tasks. Boud (1995) asserted that students forget $90 \%$ of whatever they learn in classes if memorization is the dominant approach to learning. By contrast, language learning through problem-based tasks can increase retention of the content (Larsson, 2001). In line with such research findings, this study also revealed that authentic problem-based tasks increase retention of vocabulary items learned by EFL learners.

One of the main problems with conventional language classes, as noted by Krashen (1985) and many other scholars is lack of opportunity to use the language. This can endanger language learners' uptake from classes and long-term retention of knowledge. Kumaravadivelu (2006) argued that the advent of learner-centered approaches to learning is a response to this need. PBL is a learner-centered approach to learning which attempts to provide the opportunity for the learners to socialize (Savery, 2006). In this way, they get more chance to practice the language; therefore, authentic problem-based tasks can be suitable tasks for language classes.

Legg (2007) showed that implementing PBL in language classes in contexts where the linguistic system used in the classes is different from the learners' first language, is more difficult for learners. This issue has been mentioned elsewhere (e.g. Larsson, 2001; Mathews-Aydinli, 2007). As this study did not use qualitative methods, this issue was not investigated; however, no particular difficulty was observed by the researchers while implementing authentic problem-based tasks.

Abdullah (1998) argued that PBL is a suitable approach for enhancement of learners' social and communicative skills. Elsewhere, Hmelo-Silver (2004), and Mathews-Aydinli (2007) noted that learners should communicate in collaborative learning approaches to convey ideas and elicit information. Wilkins (1972), on the other hand, considered vocabulary as an essential component of effective communication. In this sense, vocabulary learning can be linked to effective communication and it can be claimed that PBL can result in effective communication among EFL learners.

This study was limited by a number of issues such as availability of problem-based materials for language classes, a step-by-step procedure defined for implementation of PBL in language classes, and scarcity of previous studies in the field to help interpret the findings. To overcome these problems the researcher designed problem-based vocabulary tasks based on Hmelo-Silver (2004) to be used in the study. In addition, the main concepts of PBL as stated by Ansarian et al. (2016) and Hmelo-Silver (2004) were used to design authentic problem-based tasks. Finally, to solve the problem with scarcity of previous research, the researcher referred to PBL studies conducted in other disciplines to enrich the discussion.

The researcher also attempted to control some of the confounding variables that could affect the findings of the study. In this study, only intermediate leaners were selected as they usually show the most effect with regard to vocabulary learning (Boer, 2001). This study only dealt with adult EFL learners since mixing young and adult learners could reduce the accuracy of the findings. It comes highly suggested by the researcher that other researchers should focus on other proficiency levels and learning styles with regard to problem-based vocabulary learning.

\section{REFERENCES}

Abdullah, M. H. (1998). Problem-based learning in language instruction: A constructivist model. Eric Digest.

Akbari, Z. (2015). Current challenges in teaching/learning English for EFL learners: The case of junior high school and high school. Procedia-Social and Behavioral Sciences, 199, 394-401.

Ansarian, L., Adlipour, A. A., Saber, M. A., \& Shafiei, E. (2016). The Impact of Problem-Based Learning on Iranian EFL Learners' Speaking Proficiency. Advances in Language and Literary Studies, 7(3), 84-94.

Azman, N., \& Shin, L. K. (2012). Problem-based learning in English for a second language classroom: Students' perspectives. International Journal of Learning, 18(6).

Boer, F. (2001). Remembering figurative idioms by hypothesizing about their origin. Prospect, 16(3), 34-43.

Boud D (1995) Assessment and learning: contradictory or complementary? In P. Knight (Ed.)Assessment for learning in higher education (pp. 35-48). London, Kogan Page.

Boud, D., \& Feletti, G. (Eds.). (1991). The challenge of problem based learning. New York: St. Martin's Press.

Coffin, P. (2013). The impact of the implementation of the PBL for EFL interdisciplinary study in a local Thai context. PBL across Cultures, 191.

Hmelo-Silver, C. E. (2004). Problem-based learning: What and how do students learn? Educational psychology review, 16(3), 235-266.

Kumaravadivelu, B. (2006). Understanding language teaching: From method to postmethod. Routledge.

Krashen, S. D. (1985). The input hypothesis: Issues and implications. Addison-Wesley Longman Ltd.

Larsson, J. (2001). Problem-Based Learning: A possible Approach to Language Education? Polonia Institute, Jagiellonian University. Retrieved on 5 May 2017 from http://www.nada.kth.se/ jla/docs/PBL.pdf 
Laufer, B., \& Hulstijn, J. (2001). Incidental vocabulary acquisition in a second language: The construct of task-induced involvement. Applied linguistics, 22(1), 1-26.

Lee, K.Y. and Kwan, C.Y. (2014). The use of problem-based learning in medical education. Retrieved from: http:// fhs.mcmaster.ca/mdprog/pbl_whatis.html

Legg, M. (2007). From question to answer: The genre of the problem-based learning tutorial at the University of Hong Kong. English for specific purposes, 26(3), 344-367.

Mar-Molinero, C., \& Stevenson, P. (Eds.). (2016). Language ideologies, policies and practices: Language and the future of Europe. Springer.

Mathews-Aydinli, J. (2007). Problem-based learning and adult English language learners. Retrieved November, 17, 2012.
Nation, I. S. (2001). Learning vocabulary in another language. Ernst Klett Sprachen.

Richard, P. (1985). Bloom's taxonomy and critical thinking instruction. Educational Leadership, 42(8), 36-39.

Savery, J. R. (2006). Overview of problem-based learning: Definitions and distinctions. Interdisciplinary Journal of Problem-based Learning, 1(1), 3.

Strevens, M. (2009). Bigger than chaos: Understanding complexity through probability. Harvard University Press.

Wesche, M., \& Paribakht, T. S. (1996). Assessing second language vocabulary knowledge: Depth versus breadth. Canadian Modern Language Review, 53(1), 13-40.

Wilkins, D. A. (1972). Linguistics in language teaching. E. Arnold,

\begin{tabular}{lll} 
Appendix A. List of words taught in the study \\
\hline Manage & Destroy & Conduct \\
Balance & Life expenses & Stamina \\
Poison & Stability & Tackle \\
Taboo & Regimen & Agnation \\
Excessive & Recovery & Stamina \\
Insist & Cuisine & Scroll \\
Habilitate & Competition & Digest \\
Ancestors & Rebound & Pier \\
Seasoning & Welfare & Commitment \\
Leaky & Resist & Import \\
\hline
\end{tabular}

